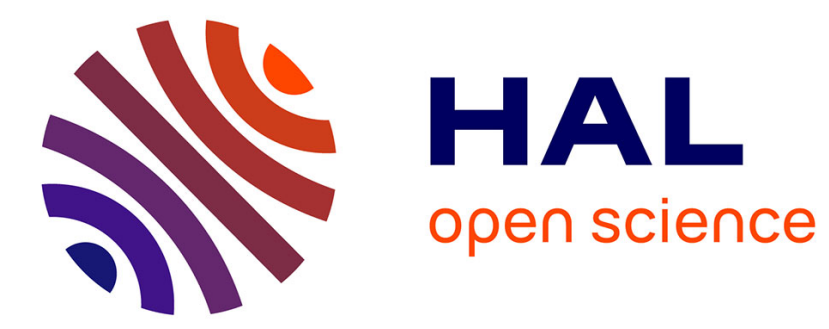

\title{
Insufficient difference
}

Lisa Lowe

\section{- To cite this version:}

Lisa Lowe. Insufficient difference. Ethnicities, 2005, 5 (3), pp.409-414. 10.1177/146879680500500308 . hal-00571831

\section{HAL Id: hal-00571831 \\ https://hal.science/hal-00571831}

Submitted on 1 Mar 2011

HAL is a multi-disciplinary open access archive for the deposit and dissemination of scientific research documents, whether they are published or not. The documents may come from teaching and research institutions in France or abroad, or from public or private research centers.
L'archive ouverte pluridisciplinaire HAL, est destinée au dépôt et à la diffusion de documents scientifiques de niveau recherche, publiés ou non, émanant des établissements d'enseignement et de recherche français ou étrangers, des laboratoires publics ou privés. 
as an unfolding diacritical process that determines us makes us realize that we cannot preexist our relation to what we come to 'know' (or 'choose' or 'fight') in any sense that gives comfort or security. Difference remains a critical resource insofar as it addresses this productive relation that cannot be known in advance. Difference is demonized in its troubling form as a determining power.

Consider the repeated warning in the US after the 9/11 attacks: if Americans change as a result of the attack - if we stop shopping or visiting Orlando - the terrorists have won. Defeating terrorism was curiously presented as a matter of remaining as we were, going on with our 'normal' lives; terrorism, we were warned, must make no difference. This exhortation coexisted with the insistence that everything had changed, post-9/11; we must live with new 'realities'. Difference is abjected; differences - in our civil liberties law, in our conduct of war, in our public life - abound.

\section{References}

J. Derrida (1998) Monolingualism of the Other; or, The Prosthesis of Origin, trans. Patrick Mensah. Stanford, CA: University of California Press.

Silva, H. (2005) 'Reveal, Innocent, Ethnic', The New York Times Style Magazine: Women's Fashion 20 February: 125.

ELLEN ROONEY is Professor of Modern Culture and Media, English and Gender Studies at Brown University. Address: Department of Modern Culture and Media, Box 1957, Brown University, Providence RI 02912, USA. [email: Ellen_Rooney@brown.edu]

\section{Insufficient difference}

\section{LISA LOWE}

University of California, San Diego

I understand the proposed 'predicament of difference' to be a provocation to think through the reasons that our projects directed toward social transformation currently confront a certain analytic exhaustion, or even banality, in the term 'difference'. The complexity of societies - so layered with multiple cultures of historical encounter, colonialism, indigeneity, 
cross-border migrations, transnational, multilingual communities, and syncretic religious cultures - is evidently inadequately understood through the analytic resources of the concept of 'difference'. There is, I think, something to be learned both by observing the reasons for the continuing desire to 'work' the term to its limits, and moreover, by generating suggested alternatives to this repetitive insistence. To this end, I make several observations.

The first observation is that the current limitations of the model for conceiving modern race, culture, and ethnicity in terms of the concept of 'difference' - whether in university study, in social or state discourses of multiculturalism, or in some cultural representations themselves - derives from Weberian sociology and its comparative method. This is not to say that philosophers, poets, and geographers did not compare one thing to another in the ancient or early modern worlds, but rather to emphasize that it was with Weber that such comparisons became an institutionalized method for producing modern knowledge about social and cultural forms. Weber is well known for having observed that social behavior in modern western society of the early 20th-century had come to be dominated more and more by goal-oriented rationality and instrumental reason, and less and less by traditional values and forms of sociality. Rational action within modern western industrial society constituted the ideal type, a heuristic proposition that founded Weber's Verstehen, or 'interpretative' sociology, against which the difference, variance, or convergence of specific social and historical instances were measured. 'For the purposes of a typological scientific analysis', he wrote, 'it is convenient to treat all irrational, affectually determined elements of behavior as factors of deviation from a conceptually pure type of rational action' (Weber, 1968[1922]: 6). This ideal-typical construction of 'pure rational action' presumed the individual within the context of modern western industrial society, and measured the different degrees of rationalization as 'deviations', by comparing concrete social instances to this normative regulatory type.

The second observation is that while the conditions of contemporary globalization have made evident the insufficiency of 'difference' as a critical analytic, perhaps the point is not only to evaluate 'difference' in terms of its adequacy, but more to situate it within the 20th-century duration of its institutionalization, to understand the reasons for its role within modern technologies of racial administration. Centering western industrial society as the normative ideal type against which 'difference' was conceived mediated a racial epistemology emerging out of an earlier conjunction of European colonialism and slavery in the 'new world'. We might understand Weber's comparative method as the institutionalization of 'difference' as a modern apparatus for apprehending and disciplining otherness, or what Michel Foucault (1991) would term a governmentality, according to which other groups, societies, and formations were studied either as analogues destined to assimilate to western classifications, or as 'pathological' deviants to be 
eliminated or suppressed (Calhoun, 1995). Modernization studies (Levy, 1966, 1972; Parsons, 1977) epitomized the western-centered developmentalism that cast other societies as culturally different 'latecomers'. Oftentimes, the Asiatic or 'oriental' has been cast as a homology to the West, in relation to the African or Muslim deviance. Sociologists of religion (Bellah, 1970) differentiated between the 'this-worldly asceticism' of Protestant Christianity in the industrial West, and the less modern, 'world-rejecting' belief systems of non-Christian societies, going so far as to argue that the social and economic development in China and Japan was due to a 'Protestant ethic analogy in Asia'. Despite the many critiques of orientalist knowledge productions by Edward Said (1977), James Clifford (1988), Talal Asad (1993), and others, the contemporary 'clash of civilizations' thesis (Huntington, 1996) demonizes Islam as an irrational 'culture of violence' antagonized by the pressures of modernization. Comparative sociologists of religion (Jurgensmeyer, 2000) recur to the cultural difference model, casting Islam as a resurgent religious fundamentalism in critical protest to the current materialism of globalization. The legacy of the comparative model was firmly established in the US sociological study of race and ethnicity, as well. As Henry Yu (2001) and Roderick Ferguson (2004) have observed, Chicago School sociologists in the early and mid 20th-century studied 'orientals' as ethnic groups who could become an assimilable 'model minority', in relation to negro racial difference constructed as irremediably, or 'pathologically', deviant. Insofar as increased international immigration in the late 20thcentury has rendered the US national discussion of race and ethnicity more global and diversified, we might also say that a pluralistic discourse of 'difference' continues to work through a governmentality that assimilates immigrant newcomers who resemble the normative ideal type and 'racializes' those whose 'cultural differences' seem too 'different' - whether the alleged cultural difference inheres in a lack of literacy or education, or a perceived threat to national security.

The third observation is that important work in the last three decades from US ethnic studies, British cultural studies, French critical theory, transnational feminism, postcolonial theory - has strategically elaborated 'difference' as more than what was assimilated or excluded by the ideal type and its normative regulations and suppressions. Scholars in US ethnic studies (Omi and Winant, 1994) and in Black British politics (Hall, 1996) theorized 'racial formation' as an ongoing dialectical process of negotiation between the state and social groups, providing for the importance of oppositional social movements and practices in actively transforming the state's definitions of both the 'whiteness' of normative citizenship and the 'difference' of racialized groups. French post-structuralism (Derrida, 1974) elaborated 'différance' as a operation dynamically revealing the means through which every paradigm or organizing structure - whether epistemological, aesthetic, social, political - constituted itself through the exclusion of 
'difference'; the constitutive exclusion leaves a trace through which the difference returns and unsettles the apparent closure of the established model. Postcolonial and transnational feminist theories have evinced the manners in which the figure of third world women has been constituted as the 'difference' both marking and enacting the limits of a range of modern universalisms (Spivak, 1987; Mohanty and Alexander, 1991).

However, alongside this critical work, it remains urgent to explore alternatives to the concept of 'difference', which nonetheless reinscribes the sociological method of 'comparison' and its normative governmentality that disciplines race, religion, gender, sexuality, and nation. As an alternative, we might consider a genealogical study that would both situate 'difference' within the modern apparatus of comparison and attempt to retrieve the fragments of mixture and convergence that are 'lost' through modern comparative procedures. We might excavate what has been suppressed under the rubric of 'difference', by considering the varieties of 'entanglements', 'imbrications', 'intimacies', or 'encounters' out of which the normative and the different have emerged as classes for modern racial understanding. In contrast to the comparative study of racial and ethnic groups as separate, comparable entities within singular histories, we might inquire instead into the historical purposes of such notions of discrete identity or necessary analogy, and would attempt to explain their emergence. A genealogical study would not only locate comparison as a paradigm coterminous with the purposes of colonialism and the modern division of labor, but it would also interpret the subjugated remainders of encounter, the foreclosed traces of mixture or creolization. Foucault referred to genealogy as an attempt 'to desubjugate historical knowledges, to set them free, or in other words, to enable them to oppose and struggle against the coercion of a unitary, formal, and scientific theoretical discourse' (Foucault, 2003: 11).

To study both the history of the modern apparatus of unitary formal theoretical discourse, and the 'entanglements' or 'imbrications' that the discourse has classified and suppressed, would entail excavating cultural geographies of encounter and mixture, not as 'origins' of singular subjects, but as epistemes, as ways of inhabiting and knowing various divisions of the social at given times. The study of the black diaspora may, for example, as Robin D.G. Kelley provocatively suggests, provide an occasion to chart more than black identities and political movements, mapping what Kelley calls 'other streams of internationalism not limited to the black world' (Kelley, 2002: 124). A study that emphasized these 'other streams' would involve a genealogy of the hemispheric conjunction of 'new world modernity', linking the forcible and voluntary migrations of black Africans with, on the one hand, the extermination of native peoples and the colonial importation of Asian contract labor at the 'end' of the slave trade to supplement the 'emancipation' of slaves, and, on the other, the rise of modern 
capitalism and the emergence of European modernity. It is, as Fernando Ortiz (1995[1940]) observed, to understand that sugar was 'mulatto' from the start. Or as Stuart Hall comments, referring to several centuries of Asian presence in the Caribbean: 'when you visit Guyana or Trinidad, you see symbolically inscribed in the faces of their peoples, the paradoxical 'truth' of Christopher Columbus' mistake: you can find 'Asia' by sailing west, if you know where to look!' (Hall, 1994: 395).

\section{References}

Asad, T. (1993) Genealogies of Religion: Discipline and Reasons of Power in Christianity and Islam. Baltimore, MD: Johns Hopkins.

Bellah, R. (1970) Beyond Belief: Essays on Religion in a Post-Traditional World. New York: Harper.

Calhoun, C. (1995) Critical Social Theory: Culture, History and the Challenge of Difference. Oxford: Blackwell.

Clifford, J. (1988) The Predicament of Culture. Cambridge, MA: Harvard University Press.

Derrida, J. (1974) Of Grammatology, trans. G.C. Spivak. Baltimore, MD: Johns Hopkins University Press.

Ferguson, R. (2004) Aberrations in Black: Toward a Queer of Color Critique. Minneapolis, MN: University of Minnesota Press.

Foucault, M. (1991) 'Governmentality', in G. Burchell, C. Gordon and P. Miller (eds) Foucault Effect: Studies in Governmentality. London: Wheatsheaf.

Foucault, M. (2003) 'Society Must Be Defended': Lectures at the Collège de France, 1975-1976, M. Bertani and A. Fontana (eds). New York: Picador.

Hall, S. (1994) 'Cultural Identity and Diaspora', in P. Williams and L. Chrisman (eds) Colonial Discourse and Postcolonial Theory, pp. 392-402. New York: Columbia.

Hall, S. (1996) 'New Ethnicities', in D. Morley, K.-H. Chen (eds) Stuart Hall: Critical Dialogues in Cultural Studies, pp. 441-49. London and New York: Routledge.

Huntington, S. (1996) The Clash of Civilizations and the Remaking of World Order. New York: Simon and Schuster.

Juergensmeyer, M. (2000) Terror in the Mind of God. Berkeley, CA: University of California Press.

Kelley, R.D.G. (2002) 'How the West was One: The African Diaspora and the ReMapping of US History', in T. Bender (ed.) Rethinking American History in a Global Age, pp. 123-47. Berkeley, CA: University of California Press.

Levy, M. (1966) Modernization and the Structure of Societies. Princeton, NJ: Princeton University Press.

Levy, M. (1972) Modernization: Latecomers and Survivors. New York: Basic Books.

Mohanty, C.T. and J.M. Alexander, eds (1991) Third World Women and the Politics of Feminism. Bloomington, IN: Indiana University Press.

Omi, M. and H. Winant (1994) Racial Formation in the United States: From the 1960s to the 1990s. New York: Routledge.

Ortiz, F. (1995[1940]) Cuban Counterpoint: Tobacco and Sugar. Durham, NC: Duke University Press.

Parsons, T. (1977) The Evolution of Societies. Englewood Cliffs, NJ: Prentice-Hall. 
Said, E. (1977) Orientalism. New York: Random House.

Spivak, G.C. (1987) In Other Worlds: Essays in Cultural Politics. New York: Methuen.

Weber, M. (1968[1922]) Economy and Society: Volume I. New York: Bedminster.

Yu, H. (2001) Thinking Orientals: Migration, Contact, and Exoticism in Modern America. Oxford: Oxford.

LISA LOWE is Professor of Comparative Literature in the Department of Literature at University of California, San Diego. Address: Department of Literature, 0410, University of California, San Diego, 9500 Gilman Drive, La Jolla CA 92093, USA. [email: Imlowe@ucsd.edu]

\section{The temporalizing of difference}

\section{CHRISTINE HELLIWELL AND BARRY HINDESS}

The Australian National University, Canberra

In his inaugural lecture as Professor of History at the University of Jena in 1789, Freidrich von Schiller observed that European voyages of discovery had provided his audience with

a spectacle which is as instructive as it is entertaining. They show us societies arrayed around us at various levels of development, as an adult might be surrounded by children of different ages, reminded by their example of what he himself once was and whence he started. A wise hand seems to have preserved these savage tribes until such time as we have progressed sufficiently in our own civilization to make useful application of this discovery, and from this mirror to recover the lost beginning of our race. (1972[1789]: 325)

The most striking features of this passage are, first, its suggestion that many of Schiller's contemporaries, living in distant parts of the world, were really anachronisms, people who belonged to an earlier time, and, second, its reference to children, as if to say that these people were less than fully mature, that their intellectual and moral capacities were relatively undeveloped. This developmental view of humanity was widely shared by educated Europeans of the Enlightenment era, and it has since remained remarkably influential in western social and political thought. It fosters the apprehension of at least two kinds of difference: that between and within peoples who are seen as being at roughly the same level (between and within, say, the English, French and Germans) and that between peoples who are seen as 